\title{
Peripheral T cell lymphoma: value of bone marrow trephine immunophenotyping
}

\author{
D M WhiTE,* A G SMITH,* J M A Whitehouse, $\dagger$ J L SMITH \\ From the Departments of *Haematology, $\ddagger$ Immunology, and + Medical Oncology, Southampton University \\ Hospitals, Southampton
}

SUMMARY Bone marrow infiltrates taken from 11 patients with peripheral $\mathrm{T}$ cell lymphoma were immunophenotyped as $T$ cell lymphoma using monoclonal antibodies on frozen bone marrow trephine biopsy specimens. In nine these were taken at diagnosis and in two after failure of treatment to eradicate lymphoma in the marrow. Patterns of infiltration were as follows: diffuse $(n=4)$, interstitial $(n=1)$, nodular $(n=1)$, focal $(n=5)$. All cases were CD3 positive and 10 were CD2 positive; five lacked expression of either CD5 or CD7, or both markers. In nine the determination of $T$ cell phenotype depended on analysis of the frozen bone marrow trephine biopsy specimen as there was no other biopsy tissue available for study. In the other two cases there was agreement between the immunophenotypes seen in lymph node and bone marrow infiltrates.

Peripheral $T$ cell lymphoma comprises a group of malignancies with diverse histology, often with an admixture of cell types. ${ }^{1-6}$ Presentation is often with extranodal disease, ${ }^{2-5}$ and the interpretation of extranodal tissue is often more complex than that of lymph node biopsy specimens in lymphoma. Further diagnostic difficulties arise as extranodal biopsy specimens are frequently fixed in formalin and so are not usually suitable for immunohistological analysis using panels of $T$ cell antibodies reactive with frozen sections or cells in suspension. Investigation of frozen tissue using monoclonal antibodies often shows heterogeneous phenotypes ${ }^{346}$ with the neoplastic cells lacking one or more of the pan $T$ cell antigens. ${ }^{5}$

In several studies bone marrow infiltration has been a common finding in peripheral $\mathrm{T}$ cell lymphoma. ${ }^{89}$ Bone marrow morphology usually resembles that seen in other infiltrated tissues, ${ }^{9}$ in contrast to B cell lymphomas where the histological appearance of the lymphoma in the marrow is frequently different from that seen elsewhere. ${ }^{10} \mathrm{~T}$ cell lymphoma in the marrow may be associated with red cell aplasia ${ }^{1112}$ or the myelodysplastic syndrome, ${ }^{1314}$ and the histological appearances of the marrow in such cases can be confusing. For example, Auger et al described three cases of $T$ cell lymphoma, one with the marrow appearances of refractory anaemia with an excess of myeloblasts, and two with hypercellular marrow tre-

Accepted for publication 16 November 1988 phine biopsy specimens which contained increased numbers of either atypical megakaryocytes or megakaryoblasts, a "left shifted" myeloid series, and either "left shifted" or dysplastic erythroid cell lines, suggestive of a myeloproliferative disorder. ${ }^{13}$ In all three cases the characteristic pattern of marrow infiltration by mature post-thymic $T$ cells became evident at a later stage in the disease.

Primary presentation with bone marrow infiltration may occur in $\mathrm{T}$ cell lymphoma in the absence of disease elsewhere ${ }^{813}$ Usually, a bone marrow biopsy specimen from a patient with asymptomatic peripheral blood cytopenia is the first evidence of disease. In this study seven of 11 patients presented with peripheral blood cytopenias, lymphomatous infiltration of the marrow, and an absence of disease at other sites that could be biopsied. Immunophenotypic analysis of frozen marrow trephine material was essential to diagnose $T$ cell lymphoma. The remaining four patients presented with lymphadenopathy and node biopsy specimens confirmed a diagnosis of non-Hodgkin's lymphoma.

\section{Material and methods}

This report of 11 cases is drawn from a larger study of 80 patients with non-Hodgkin's lymphoma. Both conventional histological assessment and immunophenotypic analysis of frozen marrow trephine biopsy specimens are carried out routinely for staging. The 11 cases studied had $\mathrm{T}$ cell infiltration confirmed by immunophenotyping their marrow trephine biopsy 
Table 1 Clinical data and pathological classification of peripheral T cell lymphoma

\begin{tabular}{|c|c|c|c|c|c|c|c|}
\hline $\begin{array}{l}\text { Case } \\
\text { No }\end{array}$ & $\begin{array}{l}\text { Agel } \\
\text { Sex }\end{array}$ & $\begin{array}{l}\text { Mode of } \\
\text { presentation }\end{array}$ & $\begin{array}{l}\text { Presenting clinical and } \\
\text { laboratory findings }\end{array}$ & $\begin{array}{l}\text { Clinical } \\
\text { stage }\end{array}$ & $\begin{array}{l}\text { Treatment and } \\
\text { outcome }\end{array}$ & $\begin{array}{l}\text { Diagnostic } \\
\text { tissue }\end{array}$ & $\begin{array}{l}\text { Histopathological } \\
\text { classification }\end{array}$ \\
\hline 1 & $26 / \mathrm{M}$ & $\begin{array}{l}\text { Pancytopenia, B } \\
\text { symptoms, } \\
\text { headaches and } \\
\text { vomiting }\end{array}$ & $\begin{array}{l}\text { Confusion, oral candida, } \\
\text { hepatosplenomegaly, } \\
\text { retroperitoneal } \\
\text { lymphadenopathy, } \\
\text { cerebrospinal fluid, } \\
\text { lymphocytosis }\end{array}$ & IVB & $\begin{array}{l}\text { Combination chemotherapy, } \\
\text { partial response; weight loss, } \\
\text { diarrhoea, pneumocystis; died } \\
\text { at } 1.8 \mathrm{~m} \text { of lymphoma } \dagger\end{array}$ & $\begin{array}{l}\text { Bone } \\
\text { marrow }\end{array}$ & $\begin{array}{l}\text { Malignant lymphoma; } \\
\text { pleomorphic medium } \\
\text { and small cell }\end{array}$ \\
\hline 2 & $63 / F$ & $\begin{array}{l}\text { Pancytopenia, B } \\
\text { symptoms, } \\
\text { drowsiness and } \\
\text { vomiting }\end{array}$ & $\begin{array}{l}\text { Generalised herpes zoster, } \\
\text { hepatosplenomegaly, } \\
\text { retroperitoneal } \\
\text { lymphadenopathy, } \\
\text { hypogammaglobulinaemia }\end{array}$ & IVB & $\begin{array}{l}\text { Intravenous acyclovir; died at } \\
1 \cdot 1 \mathrm{~m} \text { of lymphoma }\end{array}$ & $\begin{array}{l}\text { Bone } \\
\text { marrow }\end{array}$ & $\begin{array}{l}\text { Malignant lymphoma; } \\
\text { pleomorphic large, } \\
\text { medium, and small cell }\end{array}$ \\
\hline 3 & $68 / \mathrm{M}$ & $\begin{array}{l}\text { Pancytopenia, B } \\
\text { symptoms }\end{array}$ & $\begin{array}{l}\text { Itching, splenic pain, } \\
\text { hepatosplenomegaly, } \\
\text { retroperitoneal } \\
\text { lymphadenopathy, } \\
\text { hypogammaglobulinaemia }\end{array}$ & IVB & $\begin{array}{l}\text { Combination chemotherapy, } \\
\text { partial response; alive at } 40 \\
\text { m. Frozen trephine biopsy } \\
\text { specimen taken after } \\
\text { treatment }\end{array}$ & $\begin{array}{l}\text { Bone } \\
\text { marrow }\end{array}$ & $\begin{array}{l}\text { Malignant lymphoma, } \\
\text { pleomorphic large, } \\
\text { medium and small cell }\end{array}$ \\
\hline 4 & $47 / \mathrm{F}$ & $\begin{array}{l}\text { Pancytopenia, } \\
\text { generalised } \\
\text { lymphadenopathy, } \\
\text { B symptoms, } \\
\text { jaundice, pleural } \\
\text { effusion }\end{array}$ & $\begin{array}{l}\mathrm{Hb} 3.9 \mathrm{~g} / \mathrm{dl} \text {, widened } \\
\text { mediastinum, retroperitoneal } \\
\text { lymphadenopathy, direct } \\
\text { Coomb's test positive, } \\
\text { hypogammaglobulinaemia }\end{array}$ & IVB & $\begin{array}{l}\text { Combination chemotherapy, } \\
\text { partial response; died at } 6 \mathrm{~m} \\
\text { of lymphoma }\end{array}$ & $\begin{array}{l}\text { Bone } \\
\text { marrow } \\
\text { lymph } \\
\text { node* }\end{array}$ & $\begin{array}{l}\text { Malignant lymphoma, } \\
\text { monomorphic medium } \\
\text { sized cell }\end{array}$ \\
\hline 5 & $68 / \mathrm{M}$ & $\begin{array}{l}\text { Lymphadenopathy } \\
\text { (previous episode } \\
\text { resolved } \\
\text { spontaneously) }\end{array}$ & $\begin{array}{l}\text { Hepatosplenomegaly, } \\
\text { retroperitoneal } \\
\text { lymphadenopathy }\end{array}$ & IVA & $\begin{array}{l}\text { Combination chemotherapy, } \\
\text { partial response; diarrhoea, } \\
\text { pneumonia; died at } 1.8 \mathrm{~m} \text { of } \\
\text { lymphoma }\end{array}$ & $\begin{array}{l}\text { Bone } \\
\text { marrow } \\
\text { lymph } \\
\text { node* }\end{array}$ & T zone lymphoma \\
\hline 6 & $62 / \mathrm{M}$ & $\begin{array}{l}\text { Lymphadenopathy, } \\
\text { B symptoms, } \\
\text { epigastric swelling }\end{array}$ & $\begin{array}{l}\text { Thrombocytopenia, } \\
\text { hepatomegaly, } \\
\text { retroperitoneal } \\
\text { lymphadenopathy, bone } \\
\text { marrow infiltrated }\end{array}$ & IVB & $\begin{array}{l}\text { Combination chemotherapy, } \\
\text { partial response; herpes zoster } \\
\text { and weight loss; alive at } 11 \mathrm{~m}\end{array}$ & $\begin{array}{l}\text { Lymph } \\
\text { rnode }\end{array}$ & Lennert's lymphoma \\
\hline 7 & $71 / \mathbf{M}$ & $\begin{array}{l}\text { Enlarged tonsil, } \\
\text { generalised } \\
\text { lymphadenopathy, } \\
\text { back pain }\end{array}$ & $\begin{array}{l}\text { Hepatomegaly, pleural } \\
\text { effusion, ascites, bone scan } \\
\text { positive; bone marrow } \\
\text { infiltrated }\end{array}$ & IVA & $\begin{array}{l}\text { Radiotherapy to tonsil and } \\
\text { spine; combination } \\
\text { chemotherapy, no response; } \\
\text { died at } 2.5 \mathrm{~m} \text { of lymphoma }{ }^{\dagger}\end{array}$ & $\begin{array}{l}\text { Lymph } \\
\text { node }\end{array}$ & $\begin{array}{l}\text { Malignant lymphoma } \\
\text { monomorphic large cell }\end{array}$ \\
\hline 8 & $62 / M$ & $\begin{array}{l}\text { Headache, ataxia, } \\
\text { thrombocytopenia }\end{array}$ & $\begin{array}{l}\text { Splenomegaly, } \\
\text { papilloedema; cranial } \\
\text { computed tomography scan } \\
\text { showed multiple } \\
\text { periventricular abnormalities }\end{array}$ & IVA & $\begin{array}{l}\text { Combination chemotherapy, } \\
\text { partial response; died at } 2.6 \mathrm{~m} \\
\text { of lymphoma }\end{array}$ & $\begin{array}{l}\text { Bone } \\
\text { marrow }\end{array}$ & $\begin{array}{l}\text { Malignant lymphoma } \\
\text { monomorphic small cell }\end{array}$ \\
\hline 9 & $44 / F$ & $\begin{array}{l}\text { Anaemia, transient } \\
\text { generalised } \\
\text { lymphadenopathy, } \\
\text { B symptoms }\end{array}$ & $\begin{array}{l}\text { Severe rheumatoid arthritis } \\
\text { in past: lymph node biopsy } \\
12 / 12 \text { previously reactive, } \\
\text { hepatosplenomegaly, } \\
\text { hypogammaglobulinaemia }\end{array}$ & IVB & $\begin{array}{l}\text { Combination chemotherapy } \\
\text { partial response; died at } 10 \mathrm{~m} \\
\text { of lymphoma }\end{array}$ & $\begin{array}{l}\text { Bone } \\
\text { marrow }\end{array}$ & $\begin{array}{l}\text { Malignant lymphoma } \\
\text { pleomorphic large cell }\end{array}$ \\
\hline 10 & $70 / F$ & $\begin{array}{l}\text { Pancytopenia, B } \\
\text { symptoms }\end{array}$ & $\begin{array}{l}\text { Intermittent } \\
\text { lymphadenopathy, previous } \\
\text { lymph node biopsy reactive; } \\
\text { lymphadenopathy developed } \\
\text { after diagnosis obtained } \\
\text { from bone marrow biopsy, } \\
\text { huge spleen }\end{array}$ & IVB & $\begin{array}{l}\text { Combination chemotherapy, } \\
\text { partial response, alive at } 13 \mathrm{~m}\end{array}$ & $\begin{array}{l}\text { Bone } \\
\text { marrow } \\
\text { lymph } \\
\text { node* }\end{array}$ & T zone lymphoma \\
\hline 11 & $69 / \mathrm{M}$ & $\begin{array}{l}\text { Anaemia, } \\
\text { leucopenia }\end{array}$ & $\begin{array}{l}\text { Splenomegaly, bone marrow } \\
\text { trephine showed pronounced } \\
\text { erythroid hypoplasia }\end{array}$ & IVA & $\begin{array}{l}\text { Combination chemotherapy } \\
\text { partial response, alive at } 20 \\
\text { m. Frozen trephine biopsy } \\
\text { specimen taken after } \\
\text { treatment }\end{array}$ & $\begin{array}{l}\text { Bone } \\
\text { marrow }\end{array}$ & $\begin{array}{l}\text { Malignant lymphoma } \\
\text { monomorphic small cell }\end{array}$ \\
\hline
\end{tabular}

*No frozen tissue preserved from lymph node.

+Time interval from diagnosis to death (months).

specimens. Details of these 11 cases are outlined in table 1.

Marrow was aspirated from the posterior iliac crest and smears were prepared routinely for staining with May-Grünwald-Giemsa. In addition, 1-2 $\mathrm{ml}$ of aspirate were taken into medium containing heparin for preparation of mononuclear cell suspensions, as described previously. ${ }^{15}$

Marrow trephine biopsy specimens were taken using an $8 \mathrm{G}$ Islam needle after removal of aspirate from the posterior iliac crest and the biopsy specimen was immediately divided in half using a razor blade. The outer half containing any cortical bone was put into formalin for conventional processing and staining 
with haematoxylin and eosin, Giemsa, periodic acid Schiff and reticulin. The inner half was immersed in Histocon (Polysciences) kept at $4^{\circ} \mathrm{C}$ for four to 12 hours and stored frozen at $-70^{\circ} \mathrm{C}$ before sectioning. Inside the cryostat (cabinet temperature $-35^{\circ} \mathrm{C}$ ) the frozen trephine biopsy specimen was mounted in OCT compound and orientated so that the long axis was perpendicular to the knife edge. Sections $(5 \mu \mathrm{m})$ were picked up on slides coated with $0.01 \%$ poly-L-lysine. The disposable blades were adjusted frequently to give a fresh cutting edge. Sections were left at room temperature overnight, fixed for 10 minutes in dry acetone, and after air drying for 10 minutes the slides were immersed in Tris buffered saline (TBS), $\mathrm{pH} 7 \cdot 6$, in preparation for staining using the alkaline phosphatase anti-alkaline phosphatase (APAAP) method described by Cordell et al..$^{16}$

The method entailed incubation with the primary monoclonal antibody, followed by goat anti-mouse Ig (GAM) and monoclonal APAAP complexes. Each incubation step lasted 30 minutes and was followed by washing in TBS. By repeating incubations with GAM and APAAP complexes (for 10 minutes each), the intensity of staining was enhanced, although care was taken not to dislodge the fragile sections during the multiple washing procedures. Finally, the alkaline phosphatase reaction was developed with a fast red, napthol-AS-Bl, dimethyl formamide substrate buffered with veronal acetate (pH9.2), containing levamisole to block any endogenous alkaline phosphatase activity. After incubation with substrate for 15 minutes slides were counterstained with haematoxylin for 20 seconds and mounted in phosphate buffered saline (PBS) and glycerol for microscopical analysis.

Infiltrates were assessed using a light microscope. Mouse anti-guinea pig immunoglobulin was used as a negative control for each trephine specimen to detect any background or non-specific staining. Three counts of 100 cells each were made in three representative areas of the infiltrate, and the percentage of positive cells calculated. The designation of the cases as $T$ cell lymphomas relied on neoplastic infiltrates in bone marrow or lymph node being positive for one or more T cell markers (CD2, CD3, CD4, CD8) and negative for the pan B cell marker CD37 and surface immunoglobulin. Individual monoclonal antibodies were judged positive if over $30 \%$ of the cells in an infiltrate were clearly positive. In case 8 , however, the marrow contained an interstitial infiltrate of small lymphoid cells which formed $40 \%$ of the total nucleated cell population, therefore monoclonal antibodies were regarded as positive if $>12 \%$ of the lymphoid cells stained positive.

\section{Results}

Salient clinical features of the cases are summarised in table 1. Seven presented with B symptoms, such as weight loss, fever, and night sweats. Two patients had experienced previous intermittent lymphadenopathy which, when biopsied, showed only reactive changes. One of the 11 patients had been treated for rheumatoid arthritis. All 11 patients had lymphomatous infiltration of marrow seen on the bone marrow trephine biopsy specimen at diagnosis.

Five patients presented with pancytopenia, four others had a less pronounced peripheral blood

Table 2 Immunophenotypes of $T$ cell infiltrates

\begin{tabular}{|c|c|c|c|c|c|c|c|c|c|c|c|c|c|c|c|c|}
\hline \multirow{3}{*}{$\begin{array}{l}\text { Case } \\
\text { No }\end{array}$} & \multicolumn{13}{|c|}{ Bone marrow infiltrate } & \multirow{3}{*}{$\begin{array}{l}\text { Class } \\
\text { II }\end{array}$} & \multirow{3}{*}{$\begin{array}{l}K i-67 \\
\text { index }\end{array}$} & \multirow{3}{*}{$\begin{array}{l}\text { Pathological } \\
\text { lymph node }\end{array}$} \\
\hline & \multicolumn{13}{|c|}{$C D$ number } & & & \\
\hline & $l$ & 2 & 3 & 4 & 5 & 7 & 8 & 16 & 25 & 38 & 45 & $45 R$ & $T 9$ & & & \\
\hline 1 & - & + & + & + & + & + & - & - & + & - & + & - & + & - & 16 & No lymph node biopsy \\
\hline 2 & - & + & + & + & + & + & - & - & ND & - & + & + & - & + & 0 & No lymph node biopsy \\
\hline $3+$ & - & + & + & + & + & + & - & - & - & - & + & - & - & - & 5 & No lymph node biopsy \\
\hline 4 & + & - & + & + & + & - & - & - & - & - & + & + & + & - & 18 & $\begin{array}{l}\text { Paraffin wax embedded } \\
\text { lymph node only }\end{array}$ \\
\hline 5 & - & + & + & ND & ND & + & - & ND & - & - & + & - & - & + & ND & No lymph node biopsy \\
\hline 6 & $\bar{*}$ & $\begin{array}{l}+ \\
+\end{array}$ & $\stackrel{+}{+}$ & $\begin{array}{l}+ \\
+\end{array}$ & $\stackrel{+}{\text { ND }}$ & $\begin{array}{l}+ \\
+\end{array}$ & $\begin{array}{l}- \\
-\end{array}$ & $\overline{\mathrm{ND}}$ & $\overline{-}$ & $\overline{\mathrm{ND}}$ & $\stackrel{+}{\text { ND }}$ & $\stackrel{+}{\text { ND }}$ & $\stackrel{+}{\text { ND }}$ & + & 0 & *Frozen lymph node biopsy \\
\hline 7 & $\overline{-}$ & + & + & - & $\stackrel{+}{\mathrm{ND}}$ & $\overline{+}$ & - & $\overline{\mathrm{ND}}$ & $\begin{array}{l}+ \\
+\end{array}$ & + & + & $\overline{\mathrm{ND}}$ & + & + & 42 & •Frozen lymph node biopsy \\
\hline 8 & - & + & + & ND & - & - & - & - & + & - & ND & - & + & + & $<1$ & No lymph node biopsy \\
\hline 9 & - & + & + & + & - & + & - & - & - & + & + & - & + & + & 62 & No lymph node biopsy \\
\hline 10 & - & + & + & + & + & + & - & - & + & - & + & - & - & - & $<1$ & $\begin{array}{l}\text { Paraffin wax embedded } \\
\text { lymph node biopsy } \\
\text { subsequent to bone marrow } \\
\text { biopsy }\end{array}$ \\
\hline $11+$ & - & - & + & + & + & - & - & ND & ND & + & + & - & + & + & 51 & No lymph node biopsy \\
\hline
\end{tabular}

ND $=$ Not done

†Frozen trephine biopsy specimen taken after treatment. 
cytopenia. Five patients presented with peripheral lymphadenopathy, three others had retroperitoneal lymphadenopathy seen on ultrasound or computed tomography scan, and the remaining three had splenomegaly without lymphadenopathy. Of the nine patients tested for serum immunoglobulins, six had decreased IgG and four of them also had low IgA and IgM. No patient had hypergammaglobulinaemia. In four of 10 patients dyserythropoiesis was seen in the marrow aspirate, two had a pronounced lack of erythroid activity, and one patient (direct Coomb's test positive) had erythroid hyperplasia. Ten patients received varying forms of combination chemotherapy. Of these, one patient failed to respond and nine had only a partial response.

Seven patients died, all of them of lymphoma. The median survival was six months and four patients were alive in partial remission at 13, 18, 20 and 40 months. In none of these four patients has lymphoma been eradicated from the marrow.

Immunophenotypic analysis of infiltrates in frozen bone marrow trephine biopsy specimens (table 2) showed that all cases were positive for CD3 and nine of 11 were positive for $\mathrm{CD} 2$. Only one was positive for CD1, a marker of immature T cells. Four cases had lost positivity for CD7, and two were also negative for CD5. Eight of nine cases were positive for CD4 and there were no cases positive for CD8.

Seven of 11 were HLA class II positive and three were positive for WR16, a CD45 restricted monoclonal antibodies which marks a subset of CD4 positive cells that act as functional supressors. ${ }^{17}$ Staining using UCHLI ${ }^{18}$ was weak and diffuse and therefore regarded as artefactual. Four of nine were positive for CD25, a marker for the IL-2 receptor. Only three of 11 were positive for CD38 (T10), an activation marker. There was variable positivity for $\mathrm{Ki}-67$, a monoclonal antibody that is a marker of proliferation. ${ }^{19}$ ranging from $0-62 \%$. The percentage positivity with the $\mathrm{Ki}-67$ index was calculated by counting 100 cells in each of the three most heavily positive areas in the infiltrate, as these areas tended to occur as isolated nodules of proliferation within an infiltrated area. All $\mathrm{T}$ cell lymphomas with a $\mathrm{Ki}-67$ index of $>10 \%$ were positive for OKT9, a marker for the transferrin receptor.

In only two cases was frozen lymph node biopsy material available for immunophenotyping, and in these cases lymph node and marrow immunophenotypes were the same.

\section{Discussion}

All 11 cases of peripheral $\mathrm{T}$ cell lymphoma investigated in this study had lymphomatous infiltration seen in conventionally processed marrow trephine biopsy specimens. Previous studies have reported a variable incidence of bone marrow disease in peripheral $\mathrm{T}$ cell lymphoma ${ }^{89}$ - up to $80 \%$ in some studies of bilateral marrow trephine biopsy specimens. ${ }^{8}$ One study by Foucar $e t$ al of a series of 176 cases of non-Hodgkin's lymphoma showed that $51 \%$ of B cell lymphomas and $65 \%$ of $\mathrm{T}$ cell lymphomas had marrow infiltration. ${ }^{10}$ As observed in previous studies we found an absence of paratrabecular infiltrates in these cases of peripheral $\mathrm{T}$ cell lymphoma. ${ }^{9}$ Due to the high incidence of bone marrow infiltration in peripheral $\mathrm{T}$ cell lymphoma reported in some studies the immunological analysis of frozen bone marrow trephine biopsy specimens is potentially a very useful technique. This was the case in this group of 11 cases where only five patients presented with peripheral lymphadenopathy (in one case lymphadenopathy developed after analysis of the frozen bone marrow trephine biopsy specimen had already established the diagnosis). In only two of five lymph node biopsy specimens was fresh tissue taken for analysis. A particular problem in diagnosis arose in the two cases presenting with central nervous system disease. Examination of cerebrospinal fluid was not diagnostic and brain biopsy was contraindicated due to thrombocytopenia. In both these cases investigation of the frozen bone marrow trephine biopsy specimen led to the diagnosis of peripheral $\mathrm{T}$ cell lymphoma. Such cases may previously have gone undiagnosed as peripheral $T$ cell lymphoma because the diagnosis often relies on the pattern of infiltration of lymph node plus immunophenotype (for example, $T$ zone lymphoma). The appearances of peripheral $T$ cell lymphoma in the marrow are not pathognomonic ${ }^{8}$ and not so easily recognisable as those seen in the lymph node. We also found that the immunological analyses of bone marrow aspirates are usually non-diagnostic.

Cases of non-Hodgkin's lymphoma have previously been investigated using frozen marrow trephine biopsy specimens. In 1983 Chilosi et al described 38 patients with B cell non-Hodgkin's lymphoma ${ }^{20}$ and in 1984 Falini et al described three cases of B-nonHodgkin's lymphoma and three cases with $\mathrm{T}$ cell proliferations in the marrow. ${ }^{21}$ In 1985 Kronland et al described frozen section analysis of two cases of peripheral $T$ cell lymphoma affecting the marrow; both were CD4 amd HLA class II positive. ${ }^{22}$

The diagnosis of $T$ cell lymphoma in the marrow is as problematic as the diagnosis of peripheral $\mathrm{T}$ cell lymphoma in other tissues - that is, there is no marker of monoclonality (light chain restriction) as there is in B cell lymphoma. Both $\mathrm{T}$ and $\mathrm{B}$ cell lymphoma are often infiltrated by large numbers of reactive or "masking" $T$ cells, ${ }^{124}$ therefore careful evaluation of the larger, more neoplastic cells for $T$ and $B$ cell markers is very important. ${ }^{23}$ 
The immunological findings of this study have confirmed previous observations in peripheral $T$ cell lymphoma. ${ }^{23}$ Most cases (eight of nine) were CD4 positive, reflecting a helper phenotype, and three of these eight cases were positive for WR 16, a marker for a subset of CD4 positive cells which act as functional suppressors. None of the 11 cases showed positivity for CD8 - that is, did not mark as a suppressor/ cytotoxic population. These results agree with previous observations that most cases of peripheral $\mathrm{T}$ cell lymphoma have a helper phenotype ${ }^{54}$ with the exception of those of Jack and Lee in $1986 .{ }^{2}$ Recent work has indicated that $T$ cell malignancies with a helper (CD4 positive) phenotype respond to treatment with deoxycoformycin, ${ }^{25}$ whereas other phenotypes do not. Therefore detailed immunophenotyping could be relevant to future treatments whether it be with cytotoxic drugs or immune modulators.

Most cases (seven of 11) were positive for HLA class II, which is a marker of activation seen in $T$ cell lymphoma ${ }^{226}$; resting $T$ cells are HLA class II negative. Two cases had lost the pan $\mathrm{T}$ cell marker CD2 but none had lost CD3, confirming the usefulness of CD3 in the diagnosis of $\mathrm{T}$ cell lymphoma. Other studies have reported the loss of most pan $T$ cell antigens in some cases of peripheral $\mathrm{T}$ cell lymphoma, especially when the lymphoma consists of larger neoplastic cells, ${ }^{23}$ thus leading to problems in the differential diagnosis between peripheral $\mathrm{T}$ cell lymphoma, diffuse aggressive B-non-Hodgkin's lymphoma, and Hodgkin's disease. In our series four of 11 cases had lost the pan T cell marker CD7 and two of 10 CD5. A total of five of 11 cases had lost at least one pan $T$ cell marker.

Three of our 11 patients showed dyserythropoietic changes in marrow aspirates taken at diagnosis: one of these manifested red cell hypoplasia which resolved following chemotherapy. Red cell aplasia is thought to be secondary to lymphocyte inhibition of erythropoiesis, ${ }^{12}$ perhaps by IL- 1 inhibiting the action of erythropoietin on erythoid precursors. "In theory this inhibition could be mediated by a malignant proliferation of $T$ cells. $T$ cell lymphoma has been reported to be associated with both red cell aplasia ${ }^{11}$ and the myelodysplastic syndromes ${ }^{1314}$ but the exact relation is unclear.

The analysis of marrow aspirate in our cases proved unhelpful in diagnosis due to the large numbers of $T$ cells present in normal marrow. For immunological analysis of marrow to be useful when lymphomatous infiltration by $T$ cells occurs, the architecture must be preserved.

$\mathrm{Ki}-67$, a marker of proliferation, has been extensively used in the investigation of non-Hodgkin's lymphoma ${ }^{27}$ It is positive in the nuclei of cells in $G_{1}$, $G_{2}, S$, and $M$ phases of the cell cycle. $G_{0}$ cells and cells entering the cycle are unstained. High percentage positivity with $\mathrm{Ki}-67$ correlates well with high grade histology in B cell lymphoma ${ }^{27}$ and is of prognostic value in non-Hodgkin's lymphoma ${ }^{28}$ No studies as yet have used this marker to assess $\mathrm{T}$ cell lymphoma in lymph node or marrow. Ki-67 positivity may be useful in choosing treatment strategies for $T$ cell lymphomas where the morphological classification into low and high grade tumours is not so clear. In cases where a marrow biopsy specimen is the sole source of diseased tissue in peripheral $\mathrm{T}$ cell lymphoma $\mathrm{Ki}-67$ may be useful in assessing the aggressiveness of the tumour.

This work was supported by a grant from the Leukaemia Research Fund, London.

\section{References}

1 Arnold A, J Bakhshi A, Jaffe ES, Waldmann TA, Korsmeyer SJ. Immunoglobulin gene rearrangements as unique clonal markers in human lymphoid neoplasms. $N$ Engl $J$ Med 1983;309:1593-9.

2 Jack AS, Lee FD. Morphological and immunohistochemical characteristics of T-cell malignant lymphomas in the west of Scotland. Histopathology 1986;10:223-34.

3 Van der Valk P, Willemze R, Meijer CJIM. Peripheral nonHodgkin's T-cell lymphomas. A clinicopathological and immunological study of 10 cases. Histopathology 1986;10: 235-49.

4 Grogan TM, Fielder K, Rangel C, et al. Peripheral T-cell lymphoma: aggressive disease with heterogeneous immunotypes. Am J Clin Pathol 1985;83:279-88.

5 Weiss CM, Crabtree GS, Rouse RV, Warnke RA. Morphologic and immunologic characterisation of 50 peripheral T-cell lymphomas. Am J Pathol 1985;118:316-24.

6 Wright DH. T-cell lymphomas. Histopathology 1986;10:321-6.

7 Warnke RA, Rouse RV. Limitations encountered in the application of tissue section immunodiagnosis to the study of lymphomas and related disorders. Hum Pathol 1985;16:326-31.

8 Hanson CA, Brunning RD, Gajl-Peczalska KJ, Frizzera G, McKenna RW. Bone marrow manifestations of peripheral Tcell lymphoma. A study of 30 cases. Am J Clin Pathol 1986;86:449-60.

9 McKenna R, Brunning R. Peripheral T-cell lymphoma (PTL): a distinctive bone marrow lesion. Blood 1982;Suppl 147a:517.

10 Foucar K, McKenna R, Frizzera G, Brunning RD. Bone marrow and blood involvement by lymphoma in relationship to the Lukes-Collins classification. Cancer 1982;49:888-97.

11 Schooley JC, Kullgren B, Allison AC. Inhibition by interleukin-1 of erythropoietin on erythroid precursors and its possible role in the pathogenesis of hypoplastic anaemias. Br J Haematol 1987;67:11-7.

12 Abkowitz JL, Kadin ME, Powell JS, Adamson JW. Pure red cell aplasia: lymphocyte inhibition of erythropoiesis. $\mathrm{Br} J$ Haematol 1986;63:59-67.

13 Auger MJ, Nash JRG, Mackie MJ. Marrow disease with T-cell lymphoma initially presenting as abnormal myelopoiesis. $J$ Clin Pathol 1986;39:134-7.

14 Copplestone JA, Mufti GJ, Hamblin TJ, Oscier DG. Immunological abnormalities in myelodysplastic syndromes II. Coexistent lymphoid or plasma cell neoplasms: a report of 20 cases unrelated to chemotherapy. Br J Haematol 1986; 63:149-59.

15 Hamblin TJ, Smith JL. Cell markers on lymphocytes in suspension. 112, ACP Broadsheet. London: Association of Clinical Pathologists/BMA, 1984. 
16 Cordell JL, Falini B, Erber WN, et al. Immunoenzymatic labelling of monoclonal anti-alkaline phosphatase (APAAP complexes). J Histochem Cytochem 1984;32:219-29.

17 Moore K, Nesbitt AM. Identification and isolation of OKT4 ${ }^{+}$ suppressor cells with the monoclonal antibody WR16. Immunology 1986;58:659-64.

18 Norton AJ, Ramsay AD, Smith SH, Beverley PCL, Isaacson PG. Monoclonal antibody (UCHLI) that recognises normal and neoplastic $\mathrm{T}$ cells in routinely fixed tissues. $J$ Clin Pathol 1986;39:399-405.

19 Gerdes J, Lemke H, Baisch H, Wacker HH, Schwab V, Stein H. Cell cycle analysis of a cell proliferation-associated human nuclear antigen defined by the monoclonal antibody $\mathrm{Ki}-67 . J$ Immunol 1984;133:1710-15.

20 Chilosi M, Pizzolo G, Fiore-Donati L, Bofill M, Janossy G. Routine immunofluorescent and histochemical analysis of bone marrow involvement of lymphoma/leukaemia: the use of cryostat sections. Br J Cancer 1983;48:763-75.

21 Falini B, Martelli MF, Tarallo F, et al. Immunohistological analysis of human bone marrow trephine biopsies using monoclonal antibodies. Br J Haematol 1984;56:365-86.

22 Kronland R, Grogan T, Spier C, et al. Immunotopographic assessment of lymphoid and plasma cell malignancies in the bone marrow. Hum Pathol 1985;16:1247-54.
23 Ramsay AD, Smith WJ, Earl HM, Souhami RL, Isaacson PG. Tcell lymphomas in adults: a clinicopathological study of eighteen cases. J Pathol 1987;152:63-76.

24 Jaffe ES, Cossman J, Fisher RI. Immunologic, pathologic and clinical analysis of peripheral T-cell lymphomas. Blood 1981;Suppl 160a:550.

25 Dearden CE, Matutes E, Hoffbrand AV, et al. Membrane phenotype and response to deoxycoformycin in mature T-cell malignancies. Br Med J 1987;295:873-5.

26 Jones DB, Wright DH, Paul D, Smith JL. Phenotypic heterogeneity displayed by T-non Hodgkin's lymphoma (T-NHL) cells dispersed from diagnostic lymph node biopsies. Hematol Oncol 1986;4:219-26.

27 Gerdes J, Dallenbach F, Lennert K. Growth fractions in malignant non-Hodgkin's lymphomas (NHL) as determined in situ with the monoclonal antibody Ki-67. Hematol Oncol 1984;2:365-71.

28 Gerdes J, Stein H, Pileri S, et al. Prognostic relevance of tumourcell growth fraction in malignant non-Hodgkin's lymphomas. Lancet 1987;ii:448-9.

Requests for reprints to: Dr D M White, Department of Haematology, Royal South Hants Hospital, Southampton, Hants, England. 